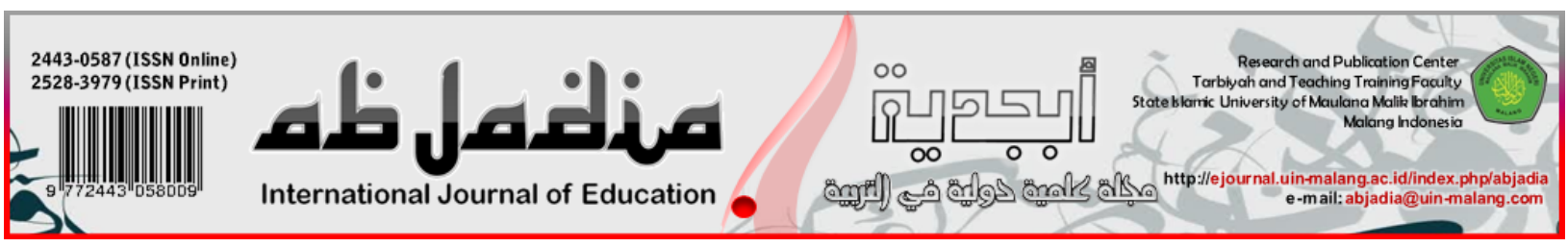

\title{
THE EFFECTIVENESS OF QUIZIZZ PLATFORM AS A MEDIA FOR THE EVALUATION OF AKIDAH AKHLAK LEARNING IN KUDUS REGENCY
}

\author{
Nailna Amanina ${ }^{*}$, Ashif Az Zafi ${ }^{2}$ \\ 1,2 IAIN Kudus, Indonesia
}

Article History:

Received: 2021-06-08

Revised: 2021-06-10

Accepted: 2021-06-20

Published : 2021-06-30

\section{Keywords:}

Quizizz's Platform, Learning Evaluation,

Akidah Akhlak

*Correspondence Address:

nailna.aman@gmail.com,

ashifazzafi@iainkudus.ac.id

\begin{abstract}
This study aims to determine the application of the Quizizz platform as a medium for evaluating Akidah Akhlak learning in Kudus Regency and to determine the effectiveness of the application of the Quizizz platform as an evaluation medium for Akidah Akhlak learning in Kudus Regency. This research uses quantitative descriptive analysis research. Then, this study gives results, namely in the evaluation of Akidah Akhlak learning in Kudus Regency during online learning using the Quizizz media platform and in this application it has a high effectiveness when implemented, with a percentage value of $56.17 \%$. The implication of this research on learning is that the online evaluation process is more effective when using the Quizizz platform, especially in daily assessments.
\end{abstract}

\section{(C) Introduction}

The Covid-19 pandemic that has occurred in Indonesia since March 2020 has made many changes in all aspects of life. Likewise in the education aspect, which has also changed due to the pandemic. Changes that occur include the technical learning that uses network connections in remote spaces, with very visible changes such as the methods, media and models used in online learning. In addition, the evaluation process has also changed, from the pre-assessment stage (question preparation), evaluation implementation to remedials and enrichment. (Kurniawan, 2021)

The implementation of the evaluation itself is very important, because an educator can find out and measure the abilities of their students through the holding of this evaluation so that they can determine the final result in the learning. Evaluations carried out in learning today are also virtual, in other words, evaluations are not carried out conventionally using paper. In the journal Lailatul Asria, he quoted from Kuncahyono, Suwandayani and Muzakki who stated that the psychology of students who experienced evaluation using a Paper Based Test or PBT could cause a high level of anxiety by these students, because when the evaluation was carried out with PBT, the supervisor's condition in The room is very influential on students' anxiety and the quality of the questions displayed in PBT is less sharp, unattractive and opaque in black and white. 
(Asria et al., 2021) Seeing this, the role of an evaluation is very influential on student learning outcomes. Student learning outcomes can be known by holding a comprehensive evaluation at the end of learning.

Seeing the shortcomings and limitations in the use or application of the PBT (Paper Based Test), the steps taken by an educator who is currently facing a pandemic can respond well to it, namely making it an opportunity for the challenges that arise in this time of the pandemic which is too distant. As in the era of 4.0 in every area of human life that takes advantage of advances in technology and information, even in human life, they cannot leave for a second not to chat with technology and information. So, in the education aspect, the use of information technology can also be used. Among the examples of this attitude, one of the Akidah Akhlak subject teachers in Kudus Regency used it as an opportunity for the emergence of challenges in learning. The learning process is carried out through Google Classroom and Whatsapp Group, while in the process of evaluating learning or procuring tests to find out student learning outcomes, it is carried out in the form of daily assessments at the end of each learning material which is carried out by utilizing the learning media or media evaluation platform Quizizz interactive, attractive and makes it easy for educators to analyze the final results of their students which can also be downloaded in excel format or form. From the implementation of this evaluation, the main thing that will be seen is the development of student learning, or in other words, student learning outcomes of one learning material. So that in knowing the learning outcomes of these students during the pandemic, especially in an Akidah Ahlak learning in Kudus Regency, namely by utilizing the Quizizz platform.

The provision of efforts to see learning outcomes can also be further observed or researched on aspects of the main components of learning, which include aspects of the method, material, educators, students and the environment. However, research focuses more on and digs deeply into the relationship between the use or application of media presence in learning, which is mainly in the activities or process of procurement evaluation. The presence of media in learning itself makes it easier to capture and respond to messages that are transmitted, because of the existence of media as a means, a way or even a tool in delivering messages, where the message referred to here is a message in the form of learning material given from a teacher or educator and received by students or students who respond to one another as a form of communication or interaction from an activity or activity process. So, it is very important the presence or existence of the media, especially in this distance learning or online learning, which requires students to be able to understand what is meant in the core of the message conveyed.

In previous research conducted by Lailatul Asria, Dwi Ratna Sari, Siti Anifatul Ngaini, Umi Muyasaroh and Fadlilah Rahmawati about the level of enthusiasm of XI MIPA 4 students at the Jepara Annual High School when evaluating Mathematics using the Quizizz platform showed that the level of student antissiasm was quite good. This 
research is also in line with the results of research by Agung Setiawan, Sri Wigati and Dwi Sulistyaningsih at SMAN 15 Semarang on Mathematics which shows an increase in student learning outcomes. (Setiawan et al., 2020) In addition, Atika Qutrotun Nada's research at MTs Nurul Huda Sedati Sidoarjo on Fiqh subjects showed a strong influence on the application of the Quizizz platform on student learning outcomes. (ROHMATIN, 2020)

In addition, the research by Trully Yetti Puspita and Ganefri in an article entitled "Development of Quizizz-based Learning Media on Basic Computers and Network Subjects" states that the level of effectiveness possessed by Quizizz learning media is applied to Basic Computer subjects. and Networks, namely effective in order to improve student learning outcomes. In this study also provides an overview of the use of Quizziz media in Basic Computer and Network subjects which are media that have good validity, practicality and effectiveness in the application process in learning which is mainly used as a learning medium. Then at each level of validity, practicality and effectiveness are detailed through the following numerical data, namely having the number 0.87 on the validity level which is owned by the use of Quizizz learning media in providing an effort to improve student learning outcomes. Furthermore, the practical level reaches 89.4 in the perspective of the teacher or teacher and 85.57 in the perspective of responses from students related to the application of Quizizz learning media in an effort to increase the level of learning achievement of students during the implementation of learning in remote classrooms. (Puspita, 2020)

Therefore, this study will examine the effect of the Quizizz platform on student learning outcomes in Akidah Akhlak subjects in Kudus Regency, which in previous studies did not mention when this media was applied to Islamic-based high school or madrasa levels, especially in one of the The subject of Islamic Religious Education is Akidah Akhlak, because the output in this subject is a practice that is practiced by students. However, before going into direct practice, a student must first master the theory or what is commonly called the Akidah Akhlak material itself and also research showing the effect of using the platform in Kudus Regency does not yet exist. So, it is very important to hold an evaluation as a measure of the ability of students to master theory or as a measure of student learning outcomes before practicing in everyday life. Then, the purpose of this study is to find out the application of the Quizizz platform as an evaluation media for Akidah Akhlak learning in Kudus Regency and to determine the effectiveness of using the Quizizz platform as an evaluation medium for Akidah Akhlak learning in Kudus Regency.

\section{[Q] Method}

\section{Identify Subsections}

This research uses descriptive quantitative research with the approach used in this research, namely the quantitative approach, in which this quantitative research is 
analyzed by deductive thinking, namely a way of thinking by finding a special thing from a general thing, in other words drawing a conclusion based on scientific theory that is valid and valid. In addition, the primary data used is data from the field or what is referred to as field research.

\section{Participant (Subject) Characteristics}

The population included in this study are students who use the Quizizz platform as a daily evaluation assessment tool in Kudus Regency, while for the sample used as respondents, the researcher uses a random sampling technique, namely the sample used is random because of the large population available. (Asria et al., 2021) In data collection techniques, researchers used a questionnaire (questionnaire) and interviews. The questionnaire distributed consists of ten questions regarding the effectiveness of using the Quizizz platform as a learning evaluation medium. The questionnaire was formed using a Likert scale which was composed of four categories, namely strongly agree, agree, disagree and strongly disagree

\section{Research Design}

Then, in the process of analyzing the data that has been collected, by calculating the results of the answers to the questionnaires that have been filled out by respondents regarding the effectiveness of using the Quizizz platform as a medium for evaluating the learning of Akidah Akhlak in Kudus Regency. After that, it was followed by a descriptive analysis of quantitative data that was arranged by giving a score for each category of answers to the questionnaire (questionnaire). Quantitative descriptive analysis is a method that is carried out by collecting various numbers and percentages of an event or thing that is concluded with general ideas or conclusions. (Tirka \& Kusumawati, 2017) The following is a table of the categories of scoring answers to the questionnaire (questionnaire).

Table 1. Scoring for Each Questionnaire Answer Category

\begin{tabular}{clc}
\hline No & \multicolumn{1}{c}{ Answer Category } & Score \\
\hline 1 & Strongly Agree & 4 \\
2 & Agree & 3 \\
3 & Disagree & 2 \\
4 & Strongly Disagree & 1 \\
\hline
\end{tabular}

Furthermore, from this score, the percentage of each indicator is calculated regarding the effectiveness of using the Quizizz platform as a learning evaluation media. Here's the formula:

$$
M=\frac{X}{Y} \times 100 \%
$$

M : Percentage of indicators on the effectiveness of using the Quizizz platform as a media for evaluation of Akidah Akhlak learning from the results of each answer by the respondent. 
$X \quad$ : The score of the answers given by the respondent to the completed questionnaire.

Y : The ideal score of the effectiveness of using the Quizizz platform as an evaluation medium for learning Akidah Akhlak

\begin{tabular}{cc} 
Table 2. Percentage of Questionnaire Responses \\
\hline Answer Category & Percentage \\
\hline Strongly Agree & $75 \%<$ score $<100 \%$ \\
Agree & $50 \%<$ score $<75 \%$ \\
Disagree & $25 \%<$ score $<50 \%$ \\
Strongly Disagree & $0 \%<$ score $<25 \%$ \\
\hline
\end{tabular}

In addition, to test the validity and reliability of the instrument, several tests of the validity and reliability of the instrument can be formulated. In this study, researchers used the product moment correlation formula mentioned by Pearson, a data can be said to be valid from a data if the calculated $r$ value is greater than the $r$ table value, namely by correlating the item score with the overall or total score. When the results of the formulation of the validity test have been completed, then review it again with the following criteria table: (Akbar, 2015)

Table 3. Instrument Validity Level

\begin{tabular}{cc}
\hline Correlation coefficient & Criteria \\
\hline $0,800-1,000$ & Very Valid \\
$0,600-0,799$ & Valid \\
$0,400-0,599$ & Quite Valid \\
$0,200-0,399$ & Not Valid \\
\hline
\end{tabular}

In testing the reliability of the instrument, the researcher used the KR20 formula, when the results of the formulation of the reliability test had been completed, it was reviewed again with the following criteria table: (Syaifulloh, 2020)

Table 4. Instrument Reliability Level

\begin{tabular}{cc}
\hline Coefficient Interval & Percentage \\
\hline $0,80-1,00$ & Very High \\
$0,60-0,79$ & High \\
$0,40-0,59$ & Medium \\
$0,20-0,39$ & Low \\
\hline
\end{tabular}

\section{Result}

Based on data from the results of filling out a questionnaire survey (a questionnaire about the effectiveness of using the Quizizz platform as a medium for evaluating Akidah Akhlak learning with each questionnaire containing ten questions from four indicators of answer categories, which have been distributed through links and questionnaires in the form of google form sheets, data analysis can be done. to be drawn into a conclusion that is in accordance with the theory.

In the distribution of the questionnaire, the respondents who responded were 35 respondents. Then, the results of the responses or responses that have been given by each 
respondent become the main data that is analyzed to be reclassified into the very high, high, low and very low levels of effectiveness of using the Quizizz platform. Following are the results of the data analysis.

In the questionnaire that was distributed as a means of collecting data and as an instrument, the questionnaire contained ten short objective questions that were answered according to each answer category. In the first question, the description of the statement about learning using Quizizz media can make it easier to understand the Akidah Akhlak material. Then for the results of the answers that have been classified are as follows.

Table 5. Answer Score of Question 1

\begin{tabular}{ccc}
\hline Answer Category & Score Calculation & Total Value \\
\hline Strongly Agree & $15 \times 4$ & 60 \\
Agree & $8 \times 3$ & 24 \\
Disagree & $7 \times 2$ & 14 \\
Strongly Disagree & $5 \times 1$ & 5 \\
\hline
\end{tabular}

Furthermore, the second question states a description of the statement about learning Akidah Akhlak using Quizizz media which is more interactive and fun. Then for a summary of the results of the classified answers are as follows.

Table 6. Answer Score of Question 2

\begin{tabular}{ccc}
\hline Answer Category & Score Calculation & Total Value \\
\hline Sangat Setuju & $10 \times 4$ & 40 \\
Setuju & $12 \times 3$ & 36 \\
Tidak Setuju & $9 \times 2$ & 18 \\
Sangat Tidak Setuju & $4 \times 1$ & 4 \\
\hline
\end{tabular}

Furthermore, the third question states a description of the statement about learning using Quizizz media to help remember the Akidah Akhlak subject matter. Then for a summary of the results of the classified answers are as follows.

Table 7. Answer Score of Question 3

\begin{tabular}{ccc}
\hline Answer Category & Score Calculation & Total Value \\
\hline Strongly Agree & $20 \times 4$ & 80 \\
Agree & $10 \times 3$ & 30 \\
Disagree & $5 \times 2$ & 10 \\
Strongly Disagree & $0 \times 1$ & 0 \\
\hline
\end{tabular}

Furthermore, in the fourth question, the statement explained about learning using Quizizz media made me like to practice Akidah Akhlak questions. Then for a summary of the results of the classified answers are as follows.

Table 8. Answer Score of Question 4

\begin{tabular}{ccc}
\hline Answer Category & Score Calculation & Total Value \\
\hline Strongly Agree & $10 \times 4$ & 40 \\
Agree & $8 \times 3$ & 24 \\
Disagree & $10 \times 2$ & 20 \\
Strongly Disagree & $7 \times 1$ & 7 \\
\hline
\end{tabular}

Furthermore, the fifth question states a description of the statement about learning using Quizizz media to train fast and agile thinking. Then for a summary of the results 
of the classified answers are as follows.

Table 9. Answer Score of Question 5

\begin{tabular}{ccc}
\hline Answer Category & Score Calculation & Total Value \\
\hline Strongly Agree & $11 \times 4$ & 44 \\
Agree & $13 \times 3$ & 39 \\
Disagree & $6 \times 2$ & 12 \\
Strongly Disagree & $5 \times 1$ & 5 \\
\hline
\end{tabular}

Furthermore, the sixth question states a description of the statement about the feeling of being happy doing Akidah Akhlak tasks with Quizizz media. Then for a summary of the results of the classified answers are as follows.

Table 10. Answer Score of Question 6

\begin{tabular}{ccc}
\hline Answer Category & Score Calculation & Total Value \\
\hline Strongly Agree & $8 \times 4$ & 32 \\
Agree & $8 \times 3$ & 24 \\
Disagree & $10 \times 2$ & 20 \\
Strongly Disagree & $9 \times 1$ & 9 \\
\hline
\end{tabular}

Furthermore, in the seventh question, it states a description of the statement about feeling happy to get a new challenge in each problem work on Quizizz. Then for a summary of the results of the classified answers are as follows.

Table 11. Answer Score of Question 7

\begin{tabular}{ccc}
\hline Answer Category & Score Calculation & Total Value \\
\hline Strongly Agree & $14 \times 4$ & 56 \\
Agree & $9 \times 3$ & 27 \\
Disagree & $7 \times 2$ & 14 \\
Strongly Disagree & $5 \times 1$ & 5 \\
\hline
\end{tabular}

Furthermore, in the eighth question, it states a description of the statement about the feeling of working on Quizizz questions seriously and enthusiastically. Then for a summary of the results of the classified answers are as follows.

Table 12. Answer Score of Question 8

\begin{tabular}{ccc}
\hline Answer Category & Score Calculation & Total Value \\
\hline Strongly Agree & $16 \times 4$ & 64 \\
Agree & $12 \times 3$ & 36 \\
Disagree & $5 \times 2$ & 10 \\
Strongly Disagree & $2 \times 1$ & 2 \\
\hline
\end{tabular}

Furthermore, the ninth question states a description of the statement about the motivated feelings of ranking the end of the Quizizz question. Then for a summary of the results of the classified answers are as follows

Table 13. Answer Score of Question 9

\begin{tabular}{ccc}
\hline Answer Category & Score Calculation & Total Value \\
\hline Strongly Agree & $20 \times 4$ & 80 \\
Agree & $10 \times 3$ & 30 \\
Disagree & $5 \times 2$ & 10 \\
Strongly Disagree & $0 \times 1$ & 0 \\
\hline
\end{tabular}


Furthermore, the tenth question states a description of the statement about learning outcomes that is increased and satisfying. Then for a summary of the results of the classified answers are as follows.

Table 14. Answer Score of Question 10

\begin{tabular}{ccc}
\hline Answer Category & Score Calculation & Total Value \\
\hline Strongly Agree & $25 \times 4$ & 100 \\
Agree & $10 \times 3$ & 30 \\
Disagree & $0 \times 2$ & 0 \\
Strongly Disagree & $0 \times 1$ & 0 \\
\hline
\end{tabular}

Furthermore, after knowing each value from the results of the answers to the questions contained in the questionnaire, the next process is to calculate the number of values based on the answer categories by adding them, as follows.

Table 15. Results of the Addition of Values by Answer Category

\begin{tabular}{ccc}
\hline Score & Total Score & Value \\
\hline 4 & $60+40+80+40+44+32+56+64+80+100$ & 596 \\
3 & $24+36+30+24+39+24+27+36+30+30$ & 300 \\
2 & $14+18+10+20+12+20+14+10+10+0$ & 128 \\
1 & $5+4+0+7+5+9+5+2+0+0$ & 37 \\
Total & 1061 & \\
\hline
\end{tabular}

Then, after the data from the classANification results of each category of the score scores are added up, the next process is to proceed with the process of calculating the percentage values of each score obtained from the distribution of questionnaires or questionnaires that have been previously classified into several categories. The calculation process is as follows, namely. (using the previous formula Chapter Research Methods).

Table 16. Percentage Results

\begin{tabular}{ccc}
\hline Score & Percentage Results & Result \\
\hline 4 & $\frac{596}{1061} \times 100 \%$ & $56.17 \%$ \\
3 & $\frac{300}{1061} \times 100 \%$ & $28.27 \%$ \\
2 & $\frac{128}{1061} \times 100 \%$ & $12.06 \%$ \\
1 & $\frac{37}{1061} \times 100 \%$ & $3.48 \%$
\end{tabular}

\section{¡imiscussion}

\section{Application of the Quizizz Media Evaluation Platform on Learning Akidah Akhlak in Kudus Regency}

The application of the Quizizz platform to Akidah Akhlak learning in Kudus Regency began as an opportunity for online learning that is currently being carried out. In addition, in responding to the increasingly digital times, the use of CBT-based evaluation media is also applied in the learning. The form of evaluation that is carried 
out at the end of the lesson is of particular concern in knowing student learning outcomes. Based on the interview with the Akidah Akhlak learning teacher, he said that in every material that the students have studied, it is necessary to have an evaluation. The evaluation that was carried out was also oriented towards distance learning (online learning) based on computers or androids, therefore the Quizizz platform was chosen as an evaluation medium in the daily assessment process after each material had been taught.

The implementation of the evaluation in the form of daily assessments is expected to be able to find out student learning outcomes related to their understanding of mastery of each material. The evaluation is given in the form of a quiz which contains between 20 and 25 questions with multiple choice questions. In addition, the reason for using this platform as an evaluation medium is the first, this media is easy to access by various devices, because it is a web tool, secondly each question can be given feedback on the right or wrong answers, then the third is at the end of the question processing session. The quiz can be observed by all participants who take the quiz in the form of ranking the results of the answers and the scores obtained. And finally, the assessment process carried out by the teacher can also make it easier, because the results of the scores obtained by students or participants in the quiz are in the form of spreadsheets in excel and are practical and more effective and efficient in terms of the time and energy used.

Furthermore, related to the application of Quizizz media in the Akidah Akhlak learning process, namely starting with virtual learning in the delivery of material by teachers of Akidah Akhlak subjects through Whatsapp Group and also Google Classroom. The material is presented in the form of a video explanation of the material being discussed. Sometimes, learning is also carried out through virtual meetings via Zoom Meeting or Google Meet. Then after the delivery of the material is complete, it is continued with a joint discussion such as questions and answers regarding the material that still needs to be discussed together. After the discussion is sufficient, then the next step is to end the learning process. The learning process continues until the material has discussed one chapter of the language being studied. Then, when all the material has been completed and arrived at the end of the chapter, an evaluation is held in the form of a daily assessment through Quizizz.

In the daily assessment process, the first step is for the teacher to create quiz questions that are uploaded on the Quizizz platform, then copy the link to the quiz question work to be shared with students via the Whatsapp Group. After that, the teacher conveys the procedures and techniques for working on the quiz questions, which later the results of the score or the value are used as the evaluation results in the daily assessment aspect. After the students understand the technicalities and procedures for doing it, the students are welcome to work on the quiz questions according to the time provided. During the process by students on their respective devices, the teacher can also monitor the process for each student in general, so that the teacher can still supervise the work of quiz questions by their students even though they are in a different and separate 
room. Then, after all the participants in the quiz or the students who worked on the quiz are finished, the teacher provides feedback in the form of questions that lead to parts of the questions which students think are generally difficult in level and which need to be added to the discussion about things that are not understood by students.

The Effectiveness of Using the Quizizz Platform as an Evaluation Media For Learning Akidah Akhlak in Kudus Regency

Based on the results of the calculation of the percentage of each sum of scores that have been classified into several categories of answers, then from the above data related to the effectiveness of using the Quizizz platform in learning Akidah Akhlak in Kudus Regency, it can be analyzed and interpreted that the use of the Quizizz platform as an evaluation medium Learning Akidah Akhlak has high effectiveness with a percentage of $56.17 \%$ with the answers from the research respondents. Then, looking at the results of the analysis and explanation, this research is in line with the research conducted by Genta Cristiyanda and Ike Sylvia regarding the effect of using Webquiz Quizizz on student sociology learning outcomes at SMAN 16 Padang, which states that the process of its use has a significant effect on the process of taking student learning outcomes. (Sylvia, 2021)

In addition, the results of this study are also in line with research conducted by Cahyani Amildah Citra and Brillian Rosy with the title of research in the form of scientific articles, namely "The Effectiveness of the Application of Learning Media Based on Quizizz Educational Games on the Learning Outcomes of Class X Student Office Technology at SMK Ketintang Surabaya Java Timur "which states that the use of Quizizz is effectively used, because it provides an increase in student learning outcomes after using the Quizizz platform learning media which is applied or implemented in a subject including in the Student Office Technology subject at SMK Ketintang Surabaya, East Java. (Rosy, 2020)

\section{国 Conclusion}

Based on the description of the research results above, the conclusions of this study include the first application of the Quizizz platform being used as an evaluation medium for Akidah Akhlak learning in Kudus Regency in order to be a tool to determine the results of student understanding achievements during learning in one chapter or one material being studied and carried out through daily assessments according to each chapter, with a daily assessment design in the form of quiz questions that have objective answers.

Then, the second is that the use of the Quizizz platform in Akidah Akhlak learning in Kudus Regency has a high effectiveness, which is proven by the percentage results showing the number $56.17 \%$. Thus, the use of the Quizizz platform as a daily evaluation medium for Akidah Akhlak learning in Kudus Regency is said to be effective. 


\section{Bibliography}

Akbar, S. (2015). Instrumen Perangkat Pembelajaran. Universitas Pendidikan Indonesia.

Asria, L., Sari, D. R., Ngaini, S. A., Rahmawati, F., Studi, P., Matematika, P., \& Magelang, U. T. (2021). Analisis Antusiasme Siswa dalam Evaluasi Belajar Menggunakan Platform Quizizz. 3(1), 1-17. https://doi.org/10.35316/alifmatika.2021.v3i1.1-17

Kurniawan, M. C. D. dan M. M. H. (2021). Pengaruh Penggunaan Quizizz sebagai Latihan Soal terhadap Hasil Belajar Siswa Kelas V SD. 03(01), 37-41.

Puspita, T. Y. (2020). Development of Quizizz-based Learning Media on Basic Computer and Network Subjects. Indonesian Journal of Educational Research and Review, 3(September), 106-112.

ROHMATIN, A. Q. N. (2020). Pengaruh Game Kuis Berbasis Android Terhadap Hasil Belajar Siswa Pada Mata Pelajaran Figh Kelas Viii Di Mts Nurul Huda Sedati Sidoarjo.

Rosy, C. A. C. dan B. (2020). Keefektifan Penggunaan Media Pembeljaran Berbasis Game Edukasi Quizziz Terhadap Hasil Belajar Teknologi Perkantoran Siswa Kelas X Smk Ketintang Surabaya. Jurnal Pendidikan Administrasi Perkantoran, 8(2).

Setiawan, A., Wigati, S., \& Sulistyaningsih, D. (2020). Implementasi Media Game Edukasi Quizizz Untuk Meningkatkan Hasil Belajar Matematika Materi Sistem Persamaan Linear Tiga Variabel Kelas X Ipa 7 Sma Negeri 15 Semarang Tahun Pelajaran 2019 /2020. 167173.

Syaifulloh, M. (2020). Pengembangan Alat Evaluasi Menggunakan Aplikasi Quizizz Pada Pembelajaran Ips Terpadu Kelas Vii Di Mts Negeri 7 Malang.

Sylvia, G. C. dan I. (2021). Pengaruh Penggunaan Webquiz Quizizz Terhadap Hasil Belajar Sosiologi Siswa Di Sman 16 Padang. Jurnal Sikola, 2(3), 174-183.

Tirka, W., \& Kusumawati, N. M. (2017). Optimalisasi Model Pembelajaran Berbasis Masalah Dengan Berbantuan Lembar Kerja Siswa ( LKS ). International Journal of Elementary Education, 1, 86-95.

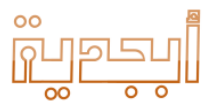

